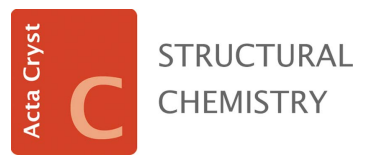

ISSN 2053-2296

Received 24 July 2019

Accepted 4 September 2019

Edited by D. S. Yufit, University of Durham, England

Keywords: pyrrolidine derivative; absolute structure; resonant scattering; circular

dichroism; crystal structure.

CCDC references: $1951413 ; 1951412$

Supporting information: this article has supporting information at journals.iucr.org/C

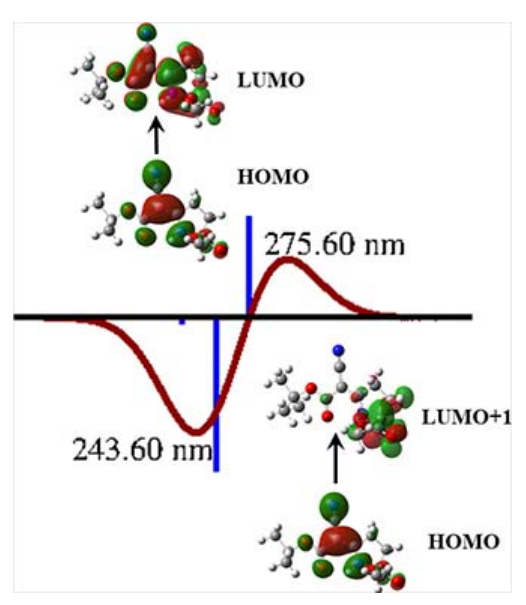

OPEN $\partial$ ACCESS

\section{Absolute structure of the chiral pyrrolidine derivative (2S)-methyl (Z)-5-(2-tert-butoxy- 1-cyano-2-oxoethylidene)pyrrolidine-2-carboxylate, a compound with low resonant scattering}

\author{
Ai Wang ${ }^{a}$ and Ulli Englert ${ }^{a, b_{*}}$
}

${ }^{a}$ Key Laboratory of Materials for Energy Conversion and Storage, Institute of Molecular Science, Shanxi University, Taiyuan, Shanxi 030006, People's Republic of China, and ' Institute of Inorganic Chemistry, RWTH Aachen University, Landoltweg 1, 52074 Aachen, Germany. *Correspondence e-mail: ullrich.englert@ac.rwth-aachen.de

The enantiopure monopyrrolidine derivative (2S)-methyl (Z)-5-(2-tert-butoxy1-cyano-2-oxoethylidene)pyrrolidine-2-carboxylate, $\mathrm{C}_{13} \mathrm{H}_{18} \mathrm{~N}_{2} \mathrm{O}_{4}$, (1), represents a potential ligand and an attractive intermediate for the synthesis of chiral metal complexes. At the molecular level, the compound features an intramolecular $\mathrm{N}-\mathrm{H} \cdots \mathrm{O}$ hydrogen bond; neighbouring molecules interact via $\mathrm{N}-\mathrm{H} \cdots \mathrm{N}$ contacts to form chains along [100]. Due to its elemental composition, resonant scattering of the target compound is entirely insignificant for diffraction experiments with Mo $K \alpha$ and small even for $\mathrm{Cu} K \alpha$ radiation. A preliminary study with the harder radiation type confirmed the chiral space group and the suitability of the single crystal chosen; as expected, the results concerning the absolute structure remained completely inconclusive. A second data collection with the longer wavelength gave satisfactory quality indicators for the correct handedness of the molecule, albeit with high standard uncertainties. The absolute configuration has been assessed independently: $\mathrm{CD}$ spectra for both enantiomers of the target molecule were calculated and the spectrum for the $S$-configured stereoisomer was in agreement with the experiment. The Cotton effect of (1) may be ascribed to $\pi-\pi^{*}$ transitions from HOMO to LUMO and from HOMO to LUMO+1. As both independent techniques agree with respect to the handedness of the target molecule, the absolute structure may be assigned with a high degree of confidence.

\section{Introduction}

Pyrrolidine derivatives have found applications as potential ligands, as organic intermediates and in medicinal chemistry. They can inhibit the activity of over-expressed protein tyrosine phosphatases (PTPs) of cancer cells and may be employed as anticancer drugs $\left(\mathrm{IC}_{50}\right.$ value is $3.65 \pm 0.08 \mu M$ ) (Chen et al., 2017). By forming imine or enamine intermediates with aldehydes and ketones, chiral monopyrrolidine derivatives have been widely used in asymmetric catalysis, and alkylation and acylation reactions of aldehydes and ketones have been achieved (Jensen et al., 2012). We report here the absolute configuration of the chiral pyrrolidine derivative (2S)-methyl (Z)-5-(2-tert-butoxy-1-cyano-2-oxoethylidene)pyrrolidine-2-carboxylate, (1) (Scheme 1). The compound has been synthesized and spectroscopically characterized by Pfaltz and co-workers (Pfaltz et al., 1977; Fritschi et al., 1988; Pfaltz, 1993); retention of the configuration at C1 may be assumed. No studies in medicinal chemistry have been conducted on (1), but a closely related compound was investigated, i.e. methyl 5-[1-cyano-2-oxo-2-(2,3,4-trimethoxyphenyl)ethylidene]prolinate was screened by the National Cancer Institution, USA, against 
Table 1

Experimental details.

For both determinations: $\mathrm{C}_{13} \mathrm{H}_{18} \mathrm{~N}_{2} \mathrm{O}_{4}, M_{\mathrm{r}}=266.29$, orthorhombic, $P 2_{1} 2_{1} 2_{1}, Z=4$. Experiments were carried out at $100 \mathrm{~K}$ using a D8 goniometer with an APEX CCD area detector. Absorption was corrected for by multi-scan methods (SADABS; Bruker, 2008). H atoms were treated by a mixture of independent and constrained refinement.

\begin{tabular}{|c|c|c|}
\hline & $(\mathbf{m o})$ & $(\mathbf{1 c u})$ \\
\hline \multicolumn{3}{|l|}{ Crystal data } \\
\hline$a, b, c(\AA)$ & $7.347(4), 10.197(6), 18.477(10)$ & 7.3731 (3), 10.1909 (4), 18.4972 (7) \\
\hline$V\left(\AA^{3}\right)$ & $1384.1(13)$ & $1389.85(9)$ \\
\hline$\mu\left(\mathrm{mm}^{-1}\right)$ & 0.10 & 0.79 \\
\hline Crystal size $(\mathrm{mm})$ & $0.35 \times 0.29 \times 0.28$ & $0.35 \times 0.29 \times 0.28$ \\
\hline \multicolumn{3}{|l|}{ Data collection } \\
\hline$R_{\text {int }}$ & 0.091 & 0.083 \\
\hline$(\sin \theta / \lambda)_{\max }\left(\AA^{-1}\right)$ & 0.583 & 0.597 \\
\hline \multicolumn{3}{|l|}{ Refinement } \\
\hline$R\left[F^{2}>2 \sigma\left(F^{2}\right)\right], w R\left(F^{2}\right), S$ & $0.051,0.124,1.08$ & $0.032,0.077,1.10$ \\
\hline No. of reflections & 2290 & 2408 \\
\hline Absolute structure parameter & $1.1(10)$ & $-0.04(12)$ \\
\hline
\end{tabular}

Computer programs: SMART (Bruker, 2001), SAINT-Plus (Bruker, 2009), SHELXS2013 (Sheldrick, 2008), SHELXL2017 (Sheldrick, 2015) and PLATON (Spek, 2009).

60 human tumour cell lines and showed moderate cell-growth inhibition at $10 \mu M$ concentration for renal cancer and leukemia

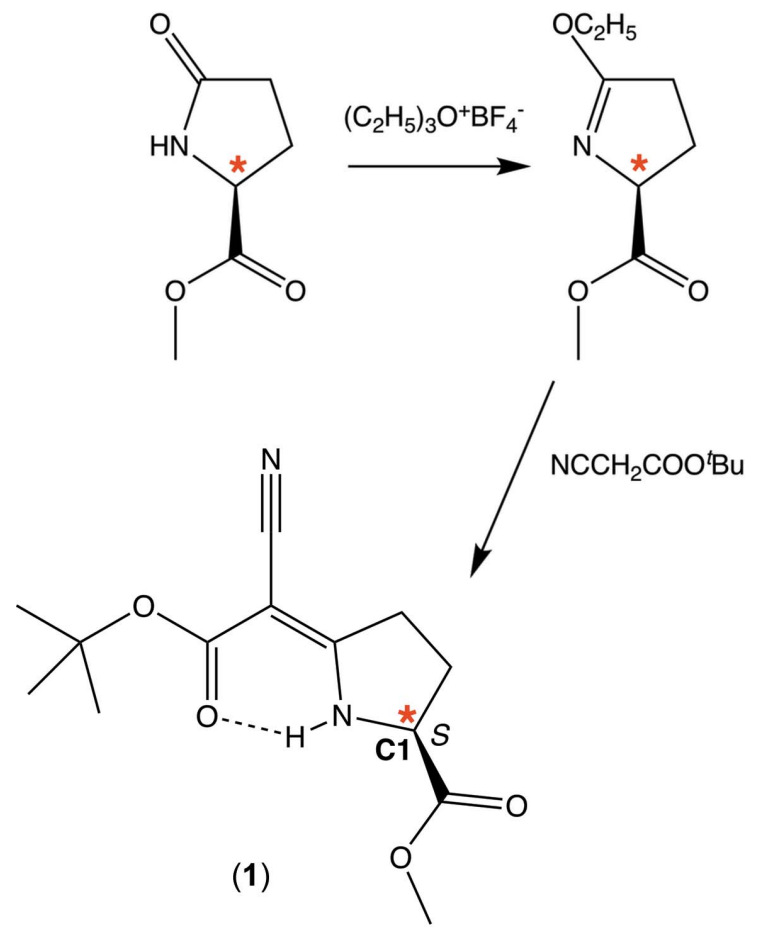

Scheme 1

(Ghinet et al., 2012). To the best of our knowledge, the structure of (1) has never been investigated and its absolute configuration has not been confirmed. Our assignment relies on a combination of diffraction experiments, experimental circular dichroism (CD) spectroscopy and theoretical calculations of these spectra. We will show that diffraction results, albeit with only a modest contribution of resonant scattering, and CD spectroscopy agree in their assignment of the absolute structure, whereas a diffraction experiment without relevant anomalous dispersion remains inconclusive.

\section{Experimental}

\subsection{Synthesis and crystallization}

All reagents were commercially available and were used without further purification. The powder diffraction experiment was recorded at the Institute of Inorganic Chemistry, RWTH Aachen University, using a Stoe imaging-plate detector (IP-PSD). The diffractogram was recorded on a flat sample at ambient temperature in transmission mode using $\mathrm{Cu} K \alpha_{1}$ radiation. The title compound was synthesized following the procedure of Pfaltz (Pfaltz et al., 1977; Fritschi et al., 1988; Pfaltz, 1993). The reaction combines $S$-configured pyroglutamic acid methyl ester and tert-butyl 2-cyanoacetate; retention of the configuration at the chiral centre (*) was expected [see Scheme 1 for a summary of the synthesis for (1) according to Pfaltz et al. (1977)] and is confirmed by the results reported in this work.

Crystals were grown by slow partial evaporation of a methanol solvent at ambient temperature over a period of one week. CHN microanalysis was carried out at the Institute of Organic Chemistry, RWTH Aachen University, using a HERAEUS CHNO-Rapid. Analysis calculated (\%) for $\mathrm{C}_{13} \mathrm{H}_{18} \mathrm{~N}_{2} \mathrm{O}_{4}$ : C 58.74, $\mathrm{H}$ 6.81, N 10.52; found: C 58.62, H 6.53, $\mathrm{N}$ 10.72. The powder X-ray diffraction (PXRD) pattern (see 


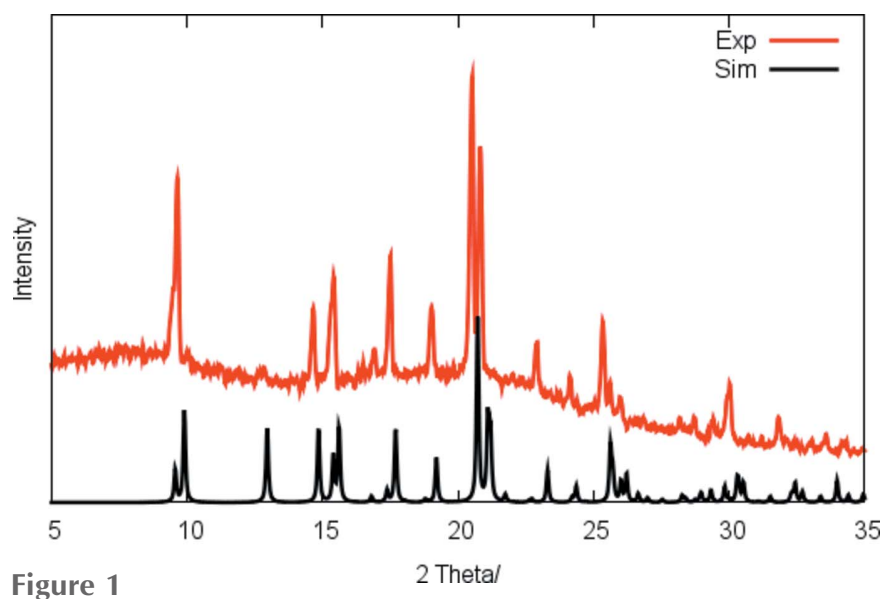

Powder X-ray diffraction pattern of (1).

Fig. 1) confirms that (1) is obtained as an essentially phasepure product; the shift of the calculated lines of two larger angles can be attributed to the different data-collection temperatures for the single-crystal and powder analyses. The IR spectrum shows an absorption associated with the triple bond in the nitrile group at $v(\mathrm{C} \equiv \mathrm{N})=2205 \mathrm{~cm}^{-1}$, in good agreement with the reported frequency of $2207 \mathrm{~cm}^{-1}$, and the ${ }^{1} \mathrm{H}$ NMR spectrum matches that available in the literature (Fritschi et al., 1988).

\subsection{Refinement}

Crystal data, data collection parameters and refinement results for both single-crystal X-ray diffraction experiments with $\mathrm{Mo} K \alpha(\mathbf{1 m o})$ and $\mathrm{Cu} K \alpha(\mathbf{1} \mathbf{c u})$ radiation are summarized in Table $1 . \mathrm{H}$ atoms attached to $\mathrm{C}$ atoms were introduced in calculated positions and treated as riding, with $U_{\text {iso }}(\mathrm{H})=$ $1.5 U_{\text {eq }}(\mathrm{C})$ for $\mathrm{CH}_{3}$ groups and $1.2 U_{\text {eq }}(\mathrm{C})$ otherwise. For the $\mathrm{H}$ atom attached to an $\mathrm{N}$ atom, the positional coordinates and an isotropic displacement parameter were refined freely. For the diffraction experiment (1mo), resonant scattering is insignificant; no information can de deduced from the refined enantiopol parameter and its very high standard uncertainty.

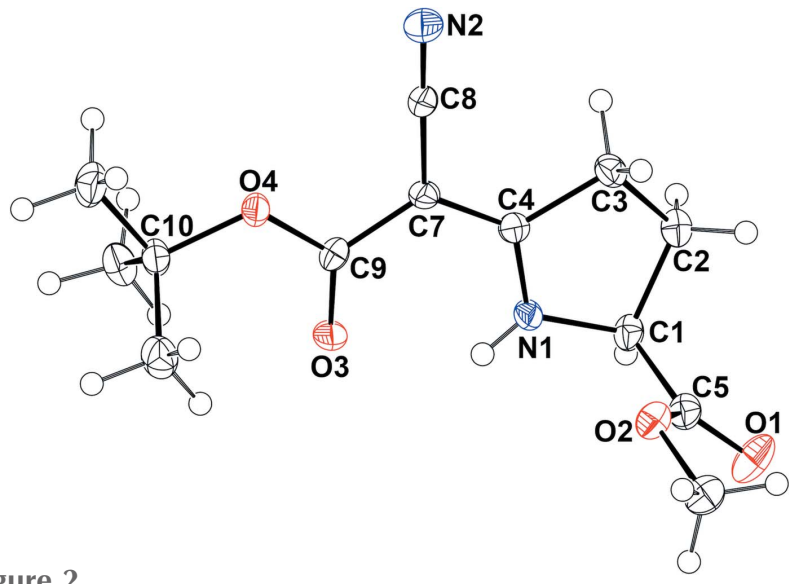

Figure 2

The asymmetric unit of (1) based on data set (1cu), with displacement ellipsoids enclosing $50 \%$ of electron density.
Table 2

Hydrogen-bond geometry $\left(\AA,^{\circ}\right)$ for $(\mathbf{1 c u})$.

\begin{tabular}{lllll}
\hline$D-\mathrm{H} \cdots A$ & $D-\mathrm{H}$ & $\mathrm{H} \cdots A$ & $D \cdots A$ & $D-\mathrm{H} \cdots A$ \\
\hline $\mathrm{N} 1-\mathrm{H} 1 \mathrm{~N} \cdots \mathrm{O} 3$ & $0.81(3)$ & $2.13(2)$ & $2.714(2)$ & $129(2)$ \\
$\mathrm{N} 1-\mathrm{H} 1 \mathrm{~N} \cdots \mathrm{N} 2^{\mathrm{i}}$ & $0.81(3)$ & $2.33(2)$ & $2.924(2)$ & $131(2)$ \\
$\mathrm{C} 11-\mathrm{H} 11 B \cdots \mathrm{O} 2^{\mathrm{ii}}$ & 0.98 & 2.60 & $3.565(3)$ & 169
\end{tabular}

Symmetry codes: (i) $x-1, y, z$; (ii) $-x+2, y+\frac{1}{2},-z+\frac{3}{2}$.

For a better comparison with the results of (1cu) on the same single crystal, the same absolute structure model was chosen in both cases.

\subsection{CD spectroscopy}

The experimental electronic circular dichroism (CD) spectrum of (1) was recorded in methanol on a Chirascan circular dichroism chiroptical spectrometer at the Institutes of Biomedical Sciences of Shanxi University; it shows a positive Cotton effect at $278.40 \mathrm{~nm}$ and a negative Cotton effect at $245.60 \mathrm{~nm}$.

\section{Results and discussion}

\subsection{Molecular structure}

The chiral compound (1) was obtained as an essentially monophasic crystalline product. In view of its elemental composition, the determination of the absolute structure was expected to be challenging. With respect to resonant scattering, we calculated values of 6 and 33 for Friedif (Flack \& Shmeuli, 2007) for diffraction experiments with $\mathrm{Mo}$ and $\mathrm{Cu}$ $K \alpha$ radiation, respectively. Even the higher second value is dangerously low if the diffraction experiments are hampered by additional complications, such as disorder or twinning. An initial data collection with our standard set-up (1mo) was performed to ensure sufficient quality for the selected crystal and to confirm the chiral space group: even for high enantiomeric excesses, a small amount of racemic solid might precipitate (Böhme \& Fels, 2013).

The second data set collected with $\mathrm{Cu} K \alpha$ radiation resulted in slightly smaller standard uncertainties; all numerical values reported below therefore refer to (1cu) (see §3.3). As expected, the enantiopure compound (1) crystallized in a chiral space group. The asymmetric unit consists of a single molecule in the space group $P 2_{1} 2_{1} 2_{1}$; Fig. 2 shows a displacement ellipsoid plot.

Atoms N1, N2, O3, O4, C3, C4 and C7-C10 define an almost planar core of the molecule shown in Fig. 3. The maximum deviation from that least-squares plane is 0.045 (2) $\AA$ for atom C3. Within the core plane, the pyrrolidine $\mathrm{N}-\mathrm{H}$ group acts as a hydrogen-bond donor towards carbonyl atom O3; the hydrogen-bond geometry is summarized in Table 2.

The pyrrolidine ring is nonplanar and its $\mathrm{C} 2$ atom is significantly displaced from the above-defined plane by $0.364(2) \AA$.

In contrast to the carboxylate group $(\mathrm{C} 9 / \mathrm{O} 3 / \mathrm{O} 4)$, the $\mathrm{C} 5 /$ $\mathrm{O} 1 / \mathrm{O} 2$ group is not coplanar with the core of the molecule but 


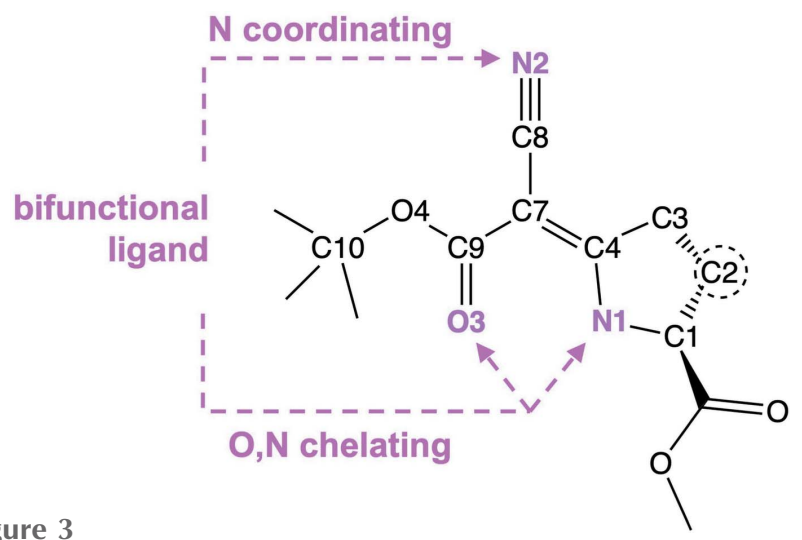

Figure 3

The planar core of (1).

subtends an angle of $86.1(2)^{\circ}$ with the least-squares plane defined by atoms N1, N2, O3, O4, C3, C4 and C7-C10 (Fig. 2). Table 3 contains selected torsion angles.

The overall conformation of the molecule suggests its use as a ditopic ligand, similar to substituted acetylacetones (Kremer \& Englert, 2018). The potential coordination sites have been indicated in Fig. 3.

\subsection{Intermolecular contacts}

The $\mathrm{H}$ atom of the pyrrolidine $\mathrm{N}-\mathrm{H}$ group represents the only potential donor for classical hydrogen bonds. In addition to the intramolecular $\mathrm{N}-\mathrm{H} \cdots \mathrm{O}$ contact described above, it is involved in an intermolecular $\mathrm{N}-\mathrm{H} \cdots \mathrm{N}$ hydrogen bond to the nitrile group of a neighbouring molecule. The resulting chain runs along [100] (Fig. 4). The closest contacts perpendicular to this chain are due to nonclassical $\mathrm{C}-\mathrm{H} \cdots \mathrm{O}$ interactions. Numerical values and symmetry operators for the short contacts have been compiled in Table 2 .

\subsection{Absolute structure}

3.3.1. Resonant scattering. Our first intensity data collection, i.e. the (1mo) data, had provided a consistent structure model without disorder and confirmed the quality of the chosen sample. As expected, however, the commonly applied methods for assigning the absolute structure gave inconclusive

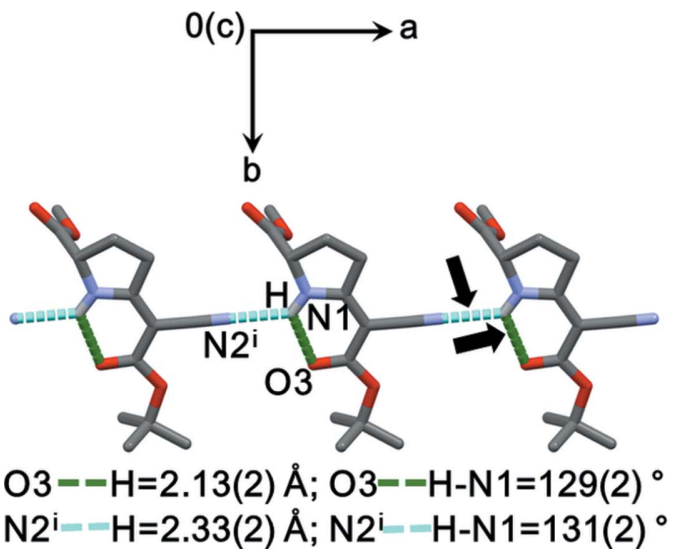

Table 3

Selected torsion angles $\left({ }^{\circ}\right)$ for $(\mathbf{1 c u})$.

\begin{tabular}{lclr}
\hline $\mathrm{C} 4-\mathrm{N} 1-\mathrm{C} 1-\mathrm{C} 5$ & $109.61(19)$ & $\mathrm{N} 1-\mathrm{C} 1-\mathrm{C} 5-\mathrm{O} 2$ & $-26.3(2)$ \\
$\mathrm{C} 4-\mathrm{N} 1-\mathrm{C} 1-\mathrm{C} 2$ & $-12.9(2)$ & $\mathrm{C} 2-\mathrm{C} 1-\mathrm{C} 5-\mathrm{O} 2$ & $90.1(2)$ \\
$\mathrm{C} 1-\mathrm{N} 1-\mathrm{C} 4-\mathrm{C} 7$ & $-179.84(18)$ & $\mathrm{C} 3-\mathrm{C} 4-\mathrm{C} 7-\mathrm{C} 8$ & $-2.4(3)$ \\
$\mathrm{C} 1-\mathrm{N} 1-\mathrm{C} 4-\mathrm{C} 3$ & $-0.6(2)$ & $\mathrm{N} 1-\mathrm{C} 4-\mathrm{C} 7-\mathrm{C} 9$ & $-2.1(3)$ \\
$\mathrm{C} 2-\mathrm{C} 3-\mathrm{C} 4-\mathrm{N} 1$ & $14.0(2)$ & $\mathrm{C} 10-\mathrm{O} 4-\mathrm{C} 9-\mathrm{O} 3$ & $-2.1(3)$ \\
$\mathrm{C} 6-\mathrm{O} 2-\mathrm{C} 5-\mathrm{O} 1$ & $-2.2(3)$ & $\mathrm{C} 4-\mathrm{C} 7-\mathrm{C} 9-\mathrm{O} 3$ & $-1.4(3)$ \\
$\mathrm{C} 6-\mathrm{O} 2-\mathrm{C} 5-\mathrm{C} 1$ & $179.93(16)$ & $\mathrm{C} 8-\mathrm{C} 7-\mathrm{C} 9-\mathrm{O} 4$ & $0.4(3)$ \\
$\mathrm{N} 1-\mathrm{C} 1-\mathrm{C} 5-\mathrm{O} 1$ & $155.73(19)$ & $\mathrm{C} 9-\mathrm{O} 4-\mathrm{C} 10-\mathrm{C} 13$ & $61.8(2)$ \\
\hline
\end{tabular}

results for (1mo) with its negligible resonant scattering. The Flack (1983, 2003), Parsons (Parsons et al., 2013) and Hooft (Hooft et al., 2010) parameters refined to values of $c a$ 1, with standard uncertainties equally large; no conclusions could be drawn from these numbers. Therefore, a second diffraction experiment with $\mathrm{Cu} K \alpha$ radiation, i.e. the (1cu) data, was performed on the same single crystal. Fractional coordinates and derived geometry parameters agreed with the results of (1mo) within error, but resonant scattering was more pronounced and led to information about the absolute structure, i.e. the Flack (1983) parameter refined to -0.04 (12); very similar values and standard uncertainties were obtained for Parsons' quotient method [-0.01 (13), Parsons et al., 2013] and Hooft's Bayesian procedure [0.01 (10), Hooft et al., 2010].

3.3.2. CD spectra. An independent assessment of the absolute structure of (1) relies on a comparison of the experimentally observed and theoretically calculated electronic circular dichroism (ECD) spectra; they are shown in Fig. 5.

The calculations were based initially on the molecular geometry obtained from (1cu). Ground-state geometry optimization and subsequent frequency calculations were performed via the density functional theory (DFT) method as implemented in GAUSSIAN09 (Frisch et al., 2009) using the B3LYP hybrid functional (Becke, 1993) and the 6$311++\mathrm{G}(2 \mathrm{~d}, \mathrm{p})$ basis set. The excitation energies, oscillator and rotational strengths of the excited singlet states for the optimized geometry were calculated according to the timedependent DFT (TDDFT) method with the same functional and basis set. The effects of the solvent (methanol) were included using the polarizable continuum model (PCM)

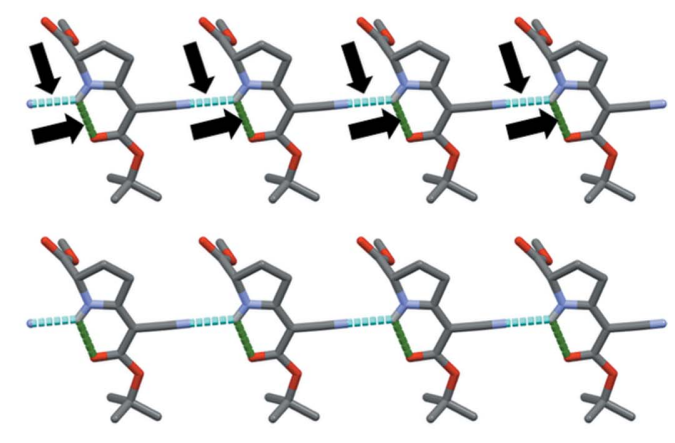

Figure 4

Intra- and intermolecular hydrogen bonds in the crystal of (1). $\mathrm{H}$ atoms not involved in hydrogen bonds have been omitted for clarity. 

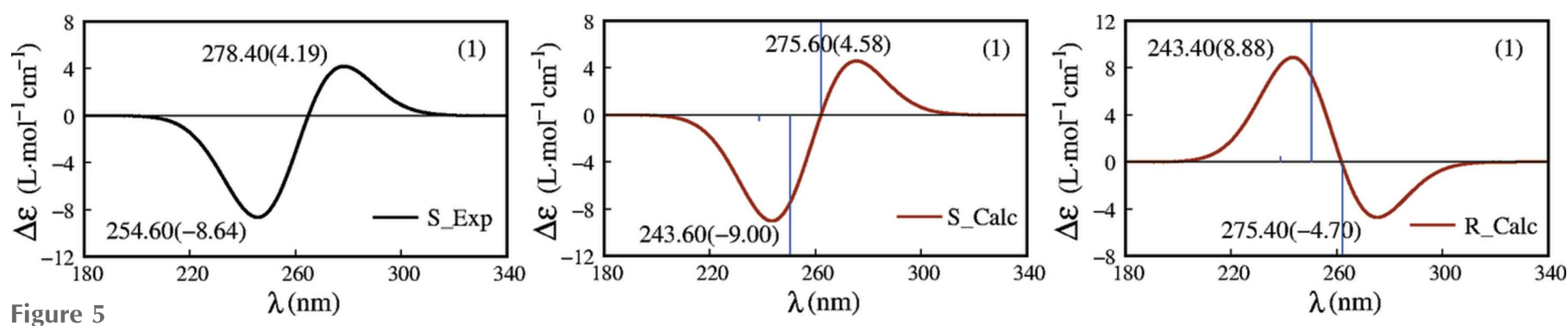

Experimental (left) and calculated CD spectra for (1) in methanol. The spectrum in the centre corresponds to the (correct) $S$ enantiomer and that on the right to the alternative $R$ enantiomer.

Table 4

Excitation wavelengths $(\lambda, \mathrm{nm})$, oscillator $(f)$ and rotational $(R, \mathrm{DBM})$ strengths and transition assignments from occupied (Occ) to virtual (Virt) orbitals.

\begin{tabular}{|c|c|c|c|c|}
\hline$\lambda$ & $f$ & $R$ & Occ-Virt & Assignments \\
\hline \multirow[t]{2}{*}{262} & 0.2670 & 0.4600 & $\mathrm{HOMO} \rightarrow \mathrm{LUMO}$ & $\pi($ coplanar $) \rightarrow \pi *($ coplanar $)(77 \%)$ \\
\hline & & & $\mathrm{HOMO} \rightarrow \mathrm{LUMO}+1$ & $\pi($ coplanar $) \rightarrow \pi *\left(\mathrm{COO}\right.$ in $\left.\mathrm{COOCH}_{3}\right)(19 \%)$ \\
\hline \multirow[t]{2}{*}{250} & 0.1642 & -0.6047 & $\mathrm{HOMO} \rightarrow \mathrm{LUMO}+1$ & $\pi($ coplanar $) \rightarrow \pi *\left(\mathrm{COO}\right.$ in $\left.\mathrm{COOCH}_{3}\right)(77 \%)$ \\
\hline & & & $\mathrm{HOMO} \rightarrow \mathrm{LUMO}$ & $\pi($ coplanar $) \rightarrow \pi *($ coplanar $)(20 \%)$ \\
\hline 239 & 0.0028 & -0.0173 & HOMO-1 $\rightarrow$ LUMO & $\sigma+n_{\mathrm{N}}+n_{\mathrm{O}} \rightarrow \pi^{*}($ coplanar $)(89 \%)$ \\
\hline
\end{tabular}

lowest energy conformer are given; they cover the spectral range $180<\lambda<350 \mathrm{~nm}$.

Using the excitation energies and rotational strengths calculated by TDDFT, theoretical CD spectra for both stereoisomers of (1) were generated as the sum of Gaussians, centred at the calculated wavelengths $\lambda_{\text {calc }}$ with integral intensities proportional to the rotational strengths $R$ of the corresponding transitions. The half bandwidths $\Gamma$ at the $\Delta \varepsilon_{\text {max }} / \mathrm{e}$ of Gaus-

(Tomasi et al., 2005) in the integral equation formalism (IEF). With the PCM, a ground-state energy of -916.95 a.u. for (1) was obtained.

3.3.3. DFT energy levels and Kohn-Sham orbitals. The DFT energy levels show a HOMU-LUMO gap of $5.25 \mathrm{eV}$. A detailed analysis of the Kohn-Sham orbitals has been graphically summarized in Fig. 6. The two lowest unoccupied orbitals are dominated by a $\pi^{*}$ region in the planar core and in the carboxylate group of the methyl ester $(\mathrm{C} 5 / \mathrm{O} 1 / \mathrm{O} 2)$. The absolute value of the energy difference between these LUMO and LUMO+1 orbitals is $0.72 \mathrm{eV}$. Both of them may well act as electron-acceptor orbitals when electrons from the HOMO and HOMO- 1 orbitals are excited. The HOMO is dominated by the $\pi$ region of the planar core of (1). The HOMO-1 essentially corresponds to a combination of $\sigma+n_{\mathrm{N}}+n_{\mathrm{O}}$ orbitals; the energy difference of the HOMO and HOMO-1 amounts to $1.28 \mathrm{eV}$.

3.3.4. Rotational strengths and transition assignments. The contribution of different transition probabilities to the chiroptical properties of (1) were analyzed. The calculated excitation energies and oscillator and rotational strengths (in velocity form), as well as the transition assignments, have been compiled in Table 4. Results for the three excitations of the sians were assumed as $\Gamma=k \lambda_{\text {calc }}{ }^{3 / 2}$ (Brown et al., 1971) with $k$ $=0.00385$ to best reproduce the experiment. The experimental spectrum and calculated spectra for both enantiomers have been compiled in Fig. 5. Ideally, experimental CD spectra of opposite enantiomers are mirror images of each other (Flack \& Bernardinelli, 2003).

It is obvious that the CD curve calculated for $S$-configured (1) is in excellent agreement with the observed curve, with only a small blue shift in the calculated maximum. The agreement confirms that our spectroscopic interpretation of the DFT results is correct.

The observed CD curve consists of two absorption bands, i.e. a positive band around $278 \mathrm{~nm}$ arising from the first $\pi-\pi^{*}$ transition in which electrons are transferred from the HOMO to the LUMO (77\%) and from the HOMO to the LUMO+1 (19\%), and a negative band around $243 \mathrm{~nm}$, which can also be ascribed to the second $\pi-\pi^{*}$ transition and a minor contribution of a $\sigma-\pi^{*}$ transition. The main contribution to this significant negative $\pi-\pi^{*}$ transition, however, is associated with the transition from HOMO to LUMO+1 (77\%) and from HOMO to LUMO $(20 \%)$. The $\sigma-\pi^{*}$ transition can be assigned to electronic excitation from HOMO-1 to LUMO. Thus, the optical properties of chiral compound (1) are mainly domi-

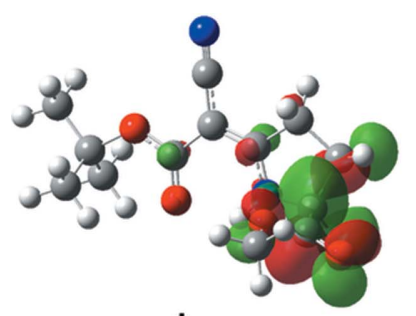

73, $\pi^{*} \mathrm{COO}$ of $\mathrm{COOCH}_{3}$

Figure 6 LUMO+1

Selected Kohn-Sham orbitals for (1).

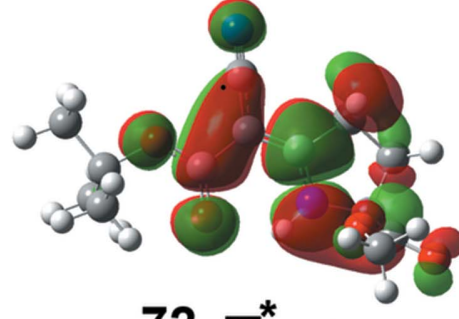

72, $\pi^{*}{ }_{\text {coplanar }}$ LUMO
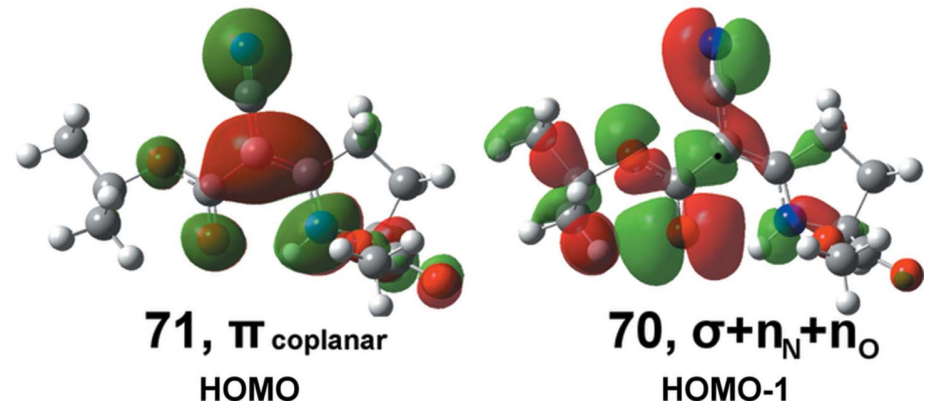
nated by a combination of $\pi-\pi *$ transitions from HOMO to LUMO and HOMO to LUMO+1.

\section{Conclusion and outlook}

The absolute structure of (1) could reliably be assigned as $S$, despite the limited contribution of resonant scattering; a lowtemperature diffraction experiment with $\mathrm{Cu} K \alpha$ radiation resulted in consistent values for the commonly applied enantiopol parameters. Their final standard uncertainties are still rather high, but our assignment is in agreement with the expected retention at the stereocentre of the starting material and could be further corroborated by the match between experimentally observed and theoretically calculated CD spectra. The associated Cotton effect was well reproduced by our TDDFT calculations, thus confirming that our methodology was suitable. We hope to use enantiopure (1) in future experiments as a ditopic ligand with the additional possibility to transfer central chirality from the ligand to its coordination complexes (Wang et al., 2015).

\section{Acknowledgements}

The authors acknowledge support from the One HundredTalent Program of Shanxi Province and thank Irmgard Kalf for help with the synthesis of (1). Funding was provided by the China Scholarship Council (scholarship to AW).

\section{References}

Becke, A. D. (1993). J. Chem. Phys. 98, 5648-5652. Böhme, U. \& Fels, S. (2013). Acta Cryst. C69, 44-46.
Brown, A., Kemp, C. M. \& Mason, S. F. (1971). J. Chem. Soc. A, pp. 751-755.

Bruker (2001). SMART. Bruker AXS Inc., Madison, Wisconsin, USA.

Bruker (2008). SADABS. Bruker AXS Inc., Madison, Wisconsin, USA.

Bruker (2009). SAINT-Plus. Bruker AXS Inc., Madison, Wisconsin, USA.

Chen, Q.-B., Xin, X.-L. \& Asia, H. A. (2017). Phys. Chem. Lett. 19, 168-171.

Flack, H. D. (1983). Acta Cryst. A39, 876-881.

Flack, H. D. (2003). Helv. Chim. Acta, 86, 905-921.

Flack, H. D. \& Bernardinelli, G. (2003). Cryst. Eng. 6, 213-223.

Flack, H. D. \& Shmueli, U. (2007). Acta Cryst. A63, 257-265.

Frisch, M. J., et al. (2009). GAUSSIAN09. Gaussian, Inc., Wallingford, CT, USA. http://www.gaussian.com.

Fritschi, H., Leutenegger, U., Siegmann, K., Pfaltz, A., Keller, W. \& Kratky, C. (1988). Helv. Chim. Acta, 71, 1541-1552.

Ghinet, A., Van Hijfte, N., Gautret, P., Rigo, B., Oulyadi, H. \& Rousseau, J. (2012). Tetrahedron, 68, 1109-1116.

Hooft, R. W. W., Straver, L. H. \& Spek, A. L. (2010). J. Appl. Cryst. 43, 665-668.

Jensen, K. J., Dickmeiss, G., Jiang, H., Albrecht, L. \& Jørgensen, K. A. (2012). Acc. Chem. Res. 45, 248-264.

Kremer, M. \& Englert, U. (2018). Z. Kristallogr. 233, 437-452.

Parsons, S., Flack, H. D. \& Wagner, T. (2013). Acta Cryst. B69, 249259.

Pfaltz, A. (1993). Acc. Chem. Res. 26, 339-345.

Pfaltz, A., Bühler, N., Neier, R., Hirai, K. \& Eschenmoser, A. (1977). Helv. Chim. Acta, 60, 2653-2672.

Sheldrick, G. M. (2008). Acta Cryst. A64, 112-122.

Sheldrick, G. M. (2015). Acta Cryst. C71, 3-8.

Spek, A. L. (2009). Acta Cryst. D65, 148-155.

Tomasi, J., Mennucci, B. \& Cammi, R. (2005). Chem. Rev. 105, 2999 3093.

Wang, A., Merkens, C. \& Englert, U. (2015). CrystEngComm, 17, 4293-4300. 


\section{supporting information}

Acta Cryst. (2019). C75, 1448-1453 [https://doi.org/10.1107/S2053229619012324]

\section{Absolute structure of the chiral pyrrolidine derivative (2S)-methyl (Z)-5-(2-tert- butoxy-1-cyano-2-oxoethylidene)pyrrolidine-2-carboxylate, a compound with low resonant scattering}

\section{Ai Wang and Ulli Englert}

Computing details

For both structures, data collection: SMART (Bruker, 2001); cell refinement: SMART (Bruker, 2001); data reduction: SAINT-Plus (Bruker, 2009); program(s) used to solve structure: SHELXS2013 (Sheldrick, 2008); program(s) used to refine structure: SHELXL2017 (Sheldrick, 2015); software used to prepare material for publication: SHELXL2017 (Sheldrick, 2015) and PLATON (Spek, 2009).

(2S)-Methyl (Z)-5-(2-tert-butoxy-1-cyano-2-oxoethylidene)pyrrolidine-2-carboxylate (1 mo)

Crystal data

$\mathrm{C}_{13} \mathrm{H}_{18} \mathrm{~N}_{2} \mathrm{O}_{4}$

$M_{r}=266.29$

Orthorhombic, $P 2{ }_{1} 2_{1} 2_{1}$

$a=7.347(4) \AA$

$b=10.197(6) \AA$

$c=18.477(10) \AA$

$V=1384.1(13) \AA^{3}$

$Z=4$

$F(000)=568$

\section{Data collection}

D8 goniometer with APEX CCD area detector diffractometer

Radiation source: Incoatec microsource

Multilayer optics monochromator

$\omega$ scans

Absorption correction: multi-scan

(SADABS; Bruker, 2008)

$T_{\min }=0.473, T_{\max }=0.745$

Refinement

Refinement on $F^{2}$

Least-squares matrix: full

$R\left[F^{2}>2 \sigma\left(F^{2}\right)\right]=0.051$

$w R\left(F^{2}\right)=0.124$

$S=1.08$

2290 reflections

180 parameters

0 restraints
$D_{\mathrm{x}}=1.278 \mathrm{Mg} \mathrm{m}^{-3}$

Mo $K \alpha$ radiation, $\lambda=0.71073 \AA$

Cell parameters from 1389 reflections

$\theta=2.3-20.4^{\circ}$

$\mu=0.10 \mathrm{~mm}^{-1}$

$T=100 \mathrm{~K}$

Block, colourless

$0.35 \times 0.29 \times 0.28 \mathrm{~mm}$

10626 measured reflections

2290 independent reflections

2051 reflections with $I>2 \sigma(I)$

$R_{\text {int }}=0.091$

$\theta_{\max }=24.5^{\circ}, \theta_{\min }=2.2^{\circ}$

$h=-8 \rightarrow 8$

$k=-11 \rightarrow 11$

$l=-21 \rightarrow 21$

Primary atom site location: structure-invariant direct methods

Hydrogen site location: mixed

$\mathrm{H}$ atoms treated by a mixture of independent and constrained refinement

$w=1 /\left[\sigma^{2}\left(F_{\mathrm{o}}^{2}\right)+(0.0228 P)^{2}+0.6063 P\right]$

where $P=\left(F_{\mathrm{o}}{ }^{2}+2 F_{\mathrm{c}}{ }^{2}\right) / 3$

$(\Delta / \sigma)_{\max }<0.001$ 
$\Delta \rho_{\max }=0.21$ e $\AA^{-3}$

$\Delta \rho_{\min }=-0.18$ e $\AA^{-3}$
Absolute structure: Flack $x$ determined using 710 quotients $[(\mathrm{I}+)-(\mathrm{I})-] /[(\mathrm{I}+)+(\mathrm{I})-]$ (Parsons $e t$ al., 2013)

Absolute structure parameter: $1.1(10)$

Special details

Geometry. All esds (except the esd in the dihedral angle between two 1.s. planes) are estimated using the full covariance matrix. The cell esds are taken into account individually in the estimation of esds in distances, angles and torsion angles; correlations between esds in cell parameters are only used when they are defined by crystal symmetry. An approximate (isotropic) treatment of cell esds is used for estimating esds involving l.s. planes.

Fractional atomic coordinates and isotropic or equivalent isotropic displacement parameters $\left(\AA^{2}\right)$

\begin{tabular}{|c|c|c|c|c|}
\hline & $x$ & $y$ & $z$ & $U_{\text {iso }} * / U_{\text {eq }}$ \\
\hline $\mathrm{O} 1$ & $0.4701(4)$ & 0.3508 & $0.57875(17)$ & $0.0391(9)$ \\
\hline $\mathrm{O} 2$ & $0.6551(4)$ & $0.4427(3)$ & $0.66052(15)$ & $0.0254(7)$ \\
\hline $\mathrm{O} 3$ & $0.7806(4)$ & 0.8818 & $0.62664(16)$ & $0.0255(7)$ \\
\hline $\mathrm{O} 4$ & $1.0663(4)$ & $0.9541(2)$ & $0.64917(14)$ & $0.0209(7)$ \\
\hline N1 & $0.7498(4)$ & 0.6385 & $0.56925(18)$ & $0.0209(8)$ \\
\hline $\mathrm{H} 1 \mathrm{~N}$ & $0.678(6)$ & $0.706(4)$ & $0.587(2)$ & $0.022(11)^{*}$ \\
\hline N2 & $1.3786(5)$ & 0.7260 & $0.5969(2)$ & $0.0288(9)$ \\
\hline $\mathrm{C} 1$ & $0.6749(6)$ & 0.5183 & $0.5387(2)$ & $0.0222(9)$ \\
\hline H1 & 0.582280 & 0.541944 & 0.501289 & $0.027 *$ \\
\hline $\mathrm{C} 2$ & $0.8415(6)$ & $0.4571(4)$ & $0.5008(2)$ & $0.0261(10)$ \\
\hline $\mathrm{H} 2 \mathrm{~A}$ & 0.843025 & 0.360684 & 0.507255 & $0.031 *$ \\
\hline $\mathrm{H} 2 \mathrm{~B}$ & 0.840489 & 0.477085 & 0.448324 & $0.031 *$ \\
\hline $\mathrm{C} 3$ & $1.0056(6)$ & $0.5202(4)$ & $0.5376(2)$ & $0.0225(9)$ \\
\hline $\mathrm{H} 3 \mathrm{~A}$ & 1.055995 & 0.462237 & 0.575657 & $0.027^{*}$ \\
\hline H3B & 1.102471 & 0.540554 & 0.502126 & $0.027 *$ \\
\hline $\mathrm{C} 4$ & $0.9278(5)$ & $0.6441(4)$ & $0.5701(2)$ & $0.0188(9)$ \\
\hline $\mathrm{C} 5$ & $0.5863(6)$ & 0.4285 & $0.5946(2)$ & $0.0250(10)$ \\
\hline C6 & $0.5754(7)$ & $0.3593(5)$ & $0.7167(2)$ & $0.0337(11)$ \\
\hline H6A & 0.447561 & 0.383309 & 0.723879 & $0.051 *$ \\
\hline H6B & 0.642325 & 0.371383 & 0.762109 & $0.051 *$ \\
\hline $\mathrm{H} 6 \mathrm{C}$ & 0.583167 & 0.267216 & 0.701744 & $0.051^{*}$ \\
\hline C7 & $1.0311(5)$ & $0.7484(4)$ & $0.5966(2)$ & $0.0191(9)$ \\
\hline $\mathrm{C} 8$ & $1.2223(6)$ & $0.7373(4)$ & $0.5960(2)$ & $0.0213(9)$ \\
\hline C9 & $0.9428(6)$ & $0.8655(4)$ & $0.6249(2)$ & $0.0195(9)$ \\
\hline $\mathrm{C} 10$ & $1.0040(6)$ & $1.0830(3)$ & $0.6775(2)$ & $0.0244(10)$ \\
\hline C11 & $1.1794(7)$ & $1.1500(4)$ & 0.6988 & $0.0343(11)$ \\
\hline H11A & 1.260278 & 1.154912 & 0.656748 & $0.051 *$ \\
\hline H11B & 1.238827 & 1.099748 & 0.737386 & $0.051 *$ \\
\hline $\mathrm{H} 11 \mathrm{C}$ & 1.152872 & 1.238765 & 0.716218 & $0.051 *$ \\
\hline C12 & $0.9109(7)$ & $1.1592(4)$ & $0.6177(2)$ & $0.0321(11)$ \\
\hline $\mathrm{H} 12 \mathrm{~A}$ & 0.985600 & 1.155885 & 0.573823 & $0.048^{*}$ \\
\hline H12B & 0.895526 & 1.250717 & 0.632817 & $0.048 *$ \\
\hline $\mathrm{H} 12 \mathrm{C}$ & 0.791425 & 1.120475 & 0.607869 & $0.048 *$ \\
\hline C13 & $0.8851(7)$ & $1.0623(4)$ & $0.7430(2)$ & $0.0339(11)$ \\
\hline $\mathrm{H} 13 \mathrm{~A}$ & 0.861422 & 1.146855 & 0.766397 & $0.051 *$ \\
\hline
\end{tabular}




\begin{tabular}{lllll}
$\mathrm{H} 13 \mathrm{~B}$ & 0.947119 & 1.003897 & 0.777191 & $0.051^{*}$ \\
$\mathrm{H} 13 \mathrm{C}$ & 0.769592 & 1.022628 & 0.728074 & $0.051^{*}$ \\
\hline
\end{tabular}

Atomic displacement parameters $\left(\AA^{2}\right)$

\begin{tabular}{lllllll}
\hline & $U^{11}$ & $U^{22}$ & $U^{33}$ & $U^{12}$ & $U^{13}$ & $U^{23}$ \\
\hline O1 & $0.043(2)$ & $0.0376(18)$ & $0.0362(19)$ & $-0.0213(16)$ & $-0.0071(16)$ & $0.0021(15)$ \\
O2 & $0.0312(16)$ & $0.0225(13)$ & $0.0224(15)$ & $-0.0040(13)$ & $-0.0023(13)$ & $0.0021(12)$ \\
O3 & $0.0196(15)$ & $0.0217(14)$ & $0.0351(17)$ & $0.0004(12)$ & $0.0010(13)$ & $-0.0057(13)$ \\
O4 & $0.0229(14)$ & $0.0140(13)$ & $0.0259(16)$ & $-0.0008(11)$ & $-0.0018(12)$ & $-0.0007(12)$ \\
N1 & $0.0199(19)$ & $0.0180(17)$ & $0.0247(19)$ & $0.0009(15)$ & $-0.0011(14)$ & $-0.0002(15)$ \\
N2 & $0.026(2)$ & $0.030(2)$ & $0.030(2)$ & $0.0012(15)$ & $-0.0002(16)$ & $-0.0005(16)$ \\
C1 & $0.027(2)$ & $0.0156(18)$ & $0.024(2)$ & $-0.0012(16)$ & $-0.0083(18)$ & $-0.0005(16)$ \\
C2 & $0.035(2)$ & $0.019(2)$ & $0.023(2)$ & $-0.001(2)$ & $-0.0034(19)$ & $-0.0032(17)$ \\
C3 & $0.027(2)$ & $0.0164(19)$ & $0.024(2)$ & $0.0032(17)$ & $0.0009(18)$ & $-0.0004(17)$ \\
C4 & $0.025(2)$ & $0.017(2)$ & $0.015(2)$ & $0.0015(17)$ & $-0.0002(17)$ & $0.0040(16)$ \\
C5 & $0.027(2)$ & $0.020(2)$ & $0.027(3)$ & $-0.0005(18)$ & $-0.0028(19)$ & $0.0000(18)$ \\
C6 & $0.039(3)$ & $0.032(2)$ & $0.030(3)$ & $-0.004(2)$ & $0.005(2)$ & $0.008(2)$ \\
C7 & $0.022(2)$ & $0.0164(18)$ & $0.019(2)$ & $0.0017(17)$ & $-0.0016(17)$ & $0.0003(16)$ \\
C8 & $0.030(2)$ & $0.0147(19)$ & $0.020(2)$ & $0.0002(17)$ & $0.0030(18)$ & $0.0011(16)$ \\
C9 & $0.023(2)$ & $0.0178(19)$ & $0.017(2)$ & $-0.0015(17)$ & $0.0005(17)$ & $0.0023(17)$ \\
C10 & $0.034(2)$ & $0.0133(18)$ & $0.026(2)$ & $0.0014(17)$ & $0.000(2)$ & $-0.0048(16)$ \\
C11 & $0.043(3)$ & $0.022(2)$ & $0.038(3)$ & $-0.006(2)$ & $-0.004(2)$ & $-0.006(2)$ \\
C12 & $0.047(3)$ & $0.020(2)$ & $0.030(3)$ & $0.009(2)$ & $0.000(2)$ & $0.0000(19)$ \\
C13 & $0.049(3)$ & $0.027(2)$ & $0.025(2)$ & $-0.004(2)$ & $0.009(2)$ & $-0.005(2)$ \\
& & & & & & \\
\hline
\end{tabular}

Geometric parameters $\left(\AA,{ }^{\circ}\right)$

\begin{tabular}{llll}
\hline $\mathrm{O} 1-\mathrm{C} 5$ & $1.201(5)$ & $\mathrm{C} 4-\mathrm{C} 7$ & $1.395(5)$ \\
$\mathrm{O} 2-\mathrm{C} 5$ & $1.327(5)$ & $\mathrm{C} 6-\mathrm{H} 6 \mathrm{~A}$ & 0.9800 \\
$\mathrm{O} 2-\mathrm{C} 6$ & $1.464(5)$ & $\mathrm{C} 6-\mathrm{H} 6 \mathrm{~B}$ & 0.9800 \\
$\mathrm{O} 3-\mathrm{C} 9$ & $1.204(5)$ & $\mathrm{C} 6-\mathrm{H} 6 \mathrm{C}$ & 0.9800 \\
$\mathrm{O} 4-\mathrm{C} 9$ & $1.357(5)$ & $\mathrm{C} 7-\mathrm{C} 8$ & $1.409(6)$ \\
$\mathrm{O} 4-\mathrm{C} 10$ & $1.487(5)$ & $\mathrm{C} 7-\mathrm{C} 9$ & $1.456(5)$ \\
$\mathrm{N} 1-\mathrm{C} 4$ & $1.309(5)$ & $\mathrm{C} 10-\mathrm{C} 13$ & $1.507(6)$ \\
$\mathrm{N} 1-\mathrm{C} 1$ & $1.457(5)$ & $\mathrm{C} 10-\mathrm{C} 11$ & $1.511(6)$ \\
$\mathrm{N} 1-\mathrm{H} 1 \mathrm{~N}$ & $0.93(4)$ & $\mathrm{C} 10-\mathrm{C} 12$ & $1.514(6)$ \\
$\mathrm{N} 2-\mathrm{C} 8$ & $1.154(5)$ & $\mathrm{C} 11-\mathrm{H} 11 \mathrm{~A}$ & 0.9800 \\
$\mathrm{C} 1-\mathrm{C} 5$ & $1.525(6)$ & $\mathrm{C} 11-\mathrm{H} 11 \mathrm{~B}$ & 0.9800 \\
$\mathrm{C} 1-\mathrm{C} 2$ & $1.543(6)$ & $\mathrm{C} 11-\mathrm{H} 11 \mathrm{C}$ & 0.9800 \\
$\mathrm{C} 1-\mathrm{H} 1$ & 1.0000 & $\mathrm{C} 12-\mathrm{H} 12 \mathrm{~A}$ & 0.9800 \\
$\mathrm{C} 2-\mathrm{C} 3$ & $1.527(6)$ & $\mathrm{C} 12-\mathrm{H} 12 \mathrm{~B}$ & 0.9800 \\
$\mathrm{C} 2-\mathrm{H} 2 \mathrm{~A}$ & 0.9900 & $\mathrm{C} 12-\mathrm{H} 12 \mathrm{C}$ & 0.9800 \\
$\mathrm{C} 2-\mathrm{H} 2 \mathrm{~B}$ & 0.9900 & $\mathrm{C} 13-\mathrm{H} 13 \mathrm{~A}$ & 0.9800 \\
$\mathrm{C} 3-\mathrm{C} 4$ & $1.510(5)$ & $\mathrm{C} 13-\mathrm{H} 13 \mathrm{~B}$ & 0.9800 \\
$\mathrm{C} 3-\mathrm{H} 3 \mathrm{~A}$ & 0.9900 & $\mathrm{C} 13-\mathrm{H} 13 \mathrm{C}$ & 0.9800 \\
$\mathrm{C} 3-\mathrm{H} 3 \mathrm{~B}$ & 0.9900 & &
\end{tabular}




$\begin{array}{ll}\mathrm{C} 5-\mathrm{O} 2-\mathrm{C} 6 & 115.8(3) \\ \mathrm{C} 9-\mathrm{O} 4-\mathrm{C} 10 & 119.9(3) \\ \mathrm{C} 4-\mathrm{N} 1-\mathrm{C} 1 & 114.7(4) \\ \mathrm{C} 4-\mathrm{N} 1-\mathrm{H} 1 \mathrm{~N} & 122(3) \\ \mathrm{C} 1-\mathrm{N} 1-\mathrm{H} 1 \mathrm{~N} & 123(3) \\ \mathrm{N} 1-\mathrm{C} 1-\mathrm{C} 5 & 113.9(3) \\ \mathrm{N} 1-\mathrm{C} 1-\mathrm{C} 2 & 102.5(3) \\ \mathrm{C} 5-\mathrm{C} 1-\mathrm{C} 2 & 113.8(3) \\ \mathrm{N} 1-\mathrm{C} 1-\mathrm{H} 1 & 108.8 \\ \mathrm{C} 5-\mathrm{C} 1-\mathrm{H} 1 & 108.8 \\ \mathrm{C} 2-\mathrm{C} 1-\mathrm{H} 1 & 108.8 \\ \mathrm{C} 3-\mathrm{C} 2-\mathrm{C} 1 & 104.6(3) \\ \mathrm{C} 3-\mathrm{C} 2-\mathrm{H} 2 \mathrm{~A} & 110.8 \\ \mathrm{C} 1-\mathrm{C} 2-\mathrm{H} 2 \mathrm{~A} & 110.8 \\ \mathrm{C} 3-\mathrm{C} 2-\mathrm{H} 2 \mathrm{~B} & 110.8 \\ \mathrm{C} 1-\mathrm{C} 2-\mathrm{H} 2 \mathrm{~B} & 110.8 \\ \mathrm{H} 2 \mathrm{~A}-\mathrm{C} 2-\mathrm{H} 2 \mathrm{~B} & 108.9 \\ \mathrm{C} 4-\mathrm{C} 3-\mathrm{C} 2 & 103.4(3) \\ \mathrm{C} 4-\mathrm{C} 3-\mathrm{H} 3 \mathrm{~A} & 111.1 \\ \mathrm{C} 2-\mathrm{C} 3-\mathrm{H} 3 \mathrm{~A} & 111.1 \\ \mathrm{C} 4-\mathrm{C} 3-\mathrm{H} 3 \mathrm{~B} & 111.1 \\ \mathrm{C} 2-\mathrm{C} 3-\mathrm{H} 3 \mathrm{~B} & 111.1 \\ \mathrm{H} 3 \mathrm{~A}-\mathrm{C} 3-\mathrm{H} 3 \mathrm{~B} & 109.1 \\ \mathrm{~N} 1-\mathrm{C} 4-\mathrm{C} 7 & 125.5(4) \\ \mathrm{N} 1-\mathrm{C} 4-\mathrm{C} 3 & 109.7(4) \\ \mathrm{C} 7-\mathrm{C} 4-\mathrm{C} 3 & 124.8(3) \\ \mathrm{O} 1-\mathrm{C} 5-\mathrm{O} 2 & 124.5(4) \\ \mathrm{O} 1-\mathrm{C} 5-\mathrm{C} 1 & 122.3(4) \\ \mathrm{O} 2-\mathrm{C} 5-\mathrm{C} 1 & 113.2(3) \\ \mathrm{O} 2-\mathrm{C} 6-\mathrm{H} 6 \mathrm{~A} & 109.5 \\ \mathrm{O} 2-\mathrm{C} 6-\mathrm{H} 6 \mathrm{~B} & 109.5 \\ \mathrm{H} 6 \mathrm{~A}-\mathrm{C} 6-\mathrm{H} 6 \mathrm{~B} & 109.5 \\ \mathrm{O} 2-\mathrm{C} 6-\mathrm{H} 6 \mathrm{C} & 109.5 \\ & \\ & \end{array}$

\begin{tabular}{|c|c|}
\hline $\mathrm{H} 6 \mathrm{~A}-\mathrm{C} 6-\mathrm{H} 6 \mathrm{C}$ & 109.5 \\
\hline $\mathrm{H} 6 \mathrm{~B}-\mathrm{C} 6-\mathrm{H} 6 \mathrm{C}$ & 109.5 \\
\hline $\mathrm{C} 4-\mathrm{C} 7-\mathrm{C} 8$ & $118.6(4)$ \\
\hline $\mathrm{C} 4-\mathrm{C} 7-\mathrm{C} 9$ & $120.6(3)$ \\
\hline $\mathrm{C} 8-\mathrm{C} 7-\mathrm{C} 9$ & $120.8(4)$ \\
\hline $\mathrm{N} 2-\mathrm{C} 8-\mathrm{C} 7$ & $178.3(5)$ \\
\hline $\mathrm{O} 3-\mathrm{C} 9-\mathrm{O} 4$ & $124.1(4)$ \\
\hline $\mathrm{O} 3-\mathrm{C} 9-\mathrm{C} 7$ & $124.3(4)$ \\
\hline $\mathrm{O} 4-\mathrm{C} 9-\mathrm{C} 7$ & $111.5(3)$ \\
\hline $\mathrm{O} 4-\mathrm{C} 10-\mathrm{C} 13$ & $109.7(3)$ \\
\hline $\mathrm{O} 4-\mathrm{C} 10-\mathrm{C} 11$ & $103.2(3)$ \\
\hline $\mathrm{C} 13-\mathrm{C} 10-\mathrm{C} 11$ & $110.4(4)$ \\
\hline $\mathrm{O} 4-\mathrm{C} 10-\mathrm{C} 12$ & $109.6(3)$ \\
\hline $\mathrm{C} 13-\mathrm{C} 10-\mathrm{C} 12$ & $113.3(4)$ \\
\hline $\mathrm{C} 11-\mathrm{C} 10-\mathrm{C} 12$ & $110.1(4)$ \\
\hline $\mathrm{C} 10-\mathrm{C} 11-\mathrm{H} 11 \mathrm{~A}$ & 109.5 \\
\hline $\mathrm{C} 10-\mathrm{C} 11-\mathrm{H} 11 \mathrm{~B}$ & 109.5 \\
\hline $\mathrm{H} 11 \mathrm{~A}-\mathrm{C} 11-\mathrm{H} 11 \mathrm{~B}$ & 109.5 \\
\hline $\mathrm{C} 10-\mathrm{C} 11-\mathrm{H} 11 \mathrm{C}$ & 109.5 \\
\hline $\mathrm{H} 11 \mathrm{~A}-\mathrm{C} 11-\mathrm{H} 11 \mathrm{C}$ & 109.5 \\
\hline $\mathrm{H} 11 \mathrm{~B}-\mathrm{C} 11-\mathrm{H} 11 \mathrm{C}$ & 109.5 \\
\hline $\mathrm{C} 10-\mathrm{C} 12-\mathrm{H} 12 \mathrm{~A}$ & 109.5 \\
\hline $\mathrm{C} 10-\mathrm{C} 12-\mathrm{H} 12 \mathrm{~B}$ & 109.5 \\
\hline $\mathrm{H} 12 \mathrm{~A}-\mathrm{C} 12-\mathrm{H} 12 \mathrm{~B}$ & 109.5 \\
\hline $\mathrm{C} 10-\mathrm{C} 12-\mathrm{H} 12 \mathrm{C}$ & 109.5 \\
\hline $\mathrm{H} 12 \mathrm{~A}-\mathrm{C} 12-\mathrm{H} 12 \mathrm{C}$ & 109.5 \\
\hline $\mathrm{H} 12 \mathrm{~B}-\mathrm{C} 12-\mathrm{H} 12 \mathrm{C}$ & 109.5 \\
\hline $\mathrm{C} 10-\mathrm{C} 13-\mathrm{H} 13 \mathrm{~A}$ & 109.5 \\
\hline $\mathrm{C} 10-\mathrm{C} 13-\mathrm{H} 13 \mathrm{~B}$ & 109.5 \\
\hline $\mathrm{H} 13 \mathrm{~A}-\mathrm{C} 13-\mathrm{H} 13 \mathrm{~B}$ & 109.5 \\
\hline $\mathrm{C} 10-\mathrm{C} 13-\mathrm{H} 13 \mathrm{C}$ & 109.5 \\
\hline $\mathrm{H} 13 \mathrm{~A}-\mathrm{C} 13-\mathrm{H} 13 \mathrm{C}$ & 109.5 \\
\hline $\mathrm{H} 13 \mathrm{~B}-\mathrm{C} 13-\mathrm{H} 13 \mathrm{C}$ & 109.5 \\
\hline
\end{tabular}

(1cu)

\section{Crystal data}

$\mathrm{C}_{13} \mathrm{H}_{18} \mathrm{~N}_{2} \mathrm{O}_{4}$

$M_{r}=266.29$

Orthorhombic, $P 2{ }_{1} 2_{1} 2_{1}$

$a=7.3731(3) \AA$

$b=10.1909$ (4) $\AA$

$c=18.4972(7) \AA$

$V=1389.85(9) \AA^{3}$

$Z=4$

$F(000)=568$
$D_{\mathrm{x}}=1.273 \mathrm{Mg} \mathrm{m}^{-3}$

$\mathrm{Cu} K \alpha$ radiation, $\lambda=1.54178 \AA$

Cell parameters from 6101 reflections

$\theta=7.4-66.3^{\circ}$

$\mu=0.79 \mathrm{~mm}^{-1}$

$T=100 \mathrm{~K}$

Block, colourless

$0.35 \times 0.29 \times 0.28 \mathrm{~mm}$ 


\section{Data collection}

D8 goniometer with APEX CCD area detector diffractometer

Radiation source: microsource

Multilayer optics monochromator

$\omega$ scans

Absorption correction: multi-scan

(SADABS; Bruker, 2008)

$T_{\min }=0.579, T_{\max }=0.753$

\section{Refinement}

Refinement on $F^{2}$

Least-squares matrix: full

$R\left[F^{2}>2 \sigma\left(F^{2}\right)\right]=0.032$

$w R\left(F^{2}\right)=0.077$

$S=1.10$

2408 reflections

181 parameters

0 restraints

Primary atom site location: other

Hydrogen site location: difference Fourier map

$\mathrm{H}$ atoms treated by a mixture of independent and constrained refinement
17945 measured reflections

2408 independent reflections

2266 reflections with $I>2 \sigma(I)$

$R_{\text {int }}=0.083$

$\theta_{\max }=67.0^{\circ}, \theta_{\min }=4.8^{\circ}$

$h=-6 \rightarrow 8$

$k=-11 \rightarrow 12$

$l=-21 \rightarrow 22$ $w=1 /\left[\sigma^{2}\left(F_{\mathrm{o}}^{2}\right)+(0.0379 P)^{2}+0.044 P\right]$

where $P=\left(F_{\mathrm{o}}^{2}+2 F_{\mathrm{c}}^{2}\right) / 3$

$(\Delta / \sigma)_{\max }<0.001$

$\Delta \rho_{\max }=0.17 \mathrm{e} \AA^{-3}$

$\Delta \rho_{\min }=-0.15$ e $\AA^{-3}$

Extinction correction: SHELXL2017

(Sheldrick, 2015),

$\mathrm{Fc}^{*}=\mathrm{kFc}\left[1+0.001 \mathrm{xFc}^{2} \lambda^{3} / \sin (2 \theta)\right]^{-1 / 4}$

Extinction coefficient: 0.0076 (11)

Absolute structure: Flack $x$ determined using 879 quotients [(I+)-(I-)]/[(I+)+(I-)] (Parsons et al., 2013)

Absolute structure parameter: -0.04 (12)

Special details

Geometry. All esds (except the esd in the dihedral angle between two 1.s. planes) are estimated using the full covariance matrix. The cell esds are taken into account individually in the estimation of esds in distances, angles and torsion angles; correlations between esds in cell parameters are only used when they are defined by crystal symmetry. An approximate (isotropic) treatment of cell esds is used for estimating esds involving l.s. planes.

Fractional atomic coordinates and isotropic or equivalent isotropic displacement parameters $\left(\AA^{2}\right)$

\begin{tabular}{lllll}
\hline & $x$ & $y$ & $z$ & $U_{\text {iso }} / U_{\text {eq }}$ \\
\hline O1 & $0.4715(2)$ & $0.35039(16)$ & $0.57878(9)$ & $0.0376(4)$ \\
O2 & $0.65579(19)$ & $0.44278(13)$ & $0.66057(7)$ & $0.0237(3)$ \\
O3 & $0.78055(18)$ & $0.88187(13)$ & $0.62654(8)$ & $0.0237(3)$ \\
O4 & $1.06691(18)$ & $0.95433(13)$ & $0.64909(7)$ & $0.0202(3)$ \\
$\mathrm{N} 1$ & $0.7503(2)$ & $0.63780(17)$ & $0.56914(9)$ & $0.0187(4)$ \\
$\mathrm{H} 1 \mathrm{~N}$ & $0.692(3)$ & $0.697(2)$ & $0.5869(12)$ & $0.018(6)^{*}$ \\
$\mathrm{~N} 2$ & $1.3791(2)$ & $0.72560(18)$ & $0.59679(10)$ & $0.0267(4)$ \\
$\mathrm{C} 1$ & $0.6751(3)$ & $0.51862(18)$ & $0.53858(11)$ & $0.0203(4)$ \\
$\mathrm{H} 1$ & 0.582817 & 0.542374 & 0.501179 & $0.024^{*}$ \\
$\mathrm{C} 2$ & $0.8411(3)$ & $0.4564(2)$ & $0.50098(11)$ & $0.0234(5)$ \\
$\mathrm{H} 2 \mathrm{~A}$ & 0.842350 & 0.360143 & 0.508020 & $0.028^{*}$ \\
$\mathrm{H} 2 \mathrm{~B}$ & 0.840037 & 0.475475 & 0.448498 & $0.028^{*}$ \\
$\mathrm{C} 3$ & $1.0061(3)$ & $0.52038(19)$ & $0.53757(11)$ & $0.0213(5)$ \\
$\mathrm{H} 3 \mathrm{~A}$ & 1.056634 & 0.462757 & 0.575653 & $0.026^{*}$ \\
$\mathrm{H} 3 \mathrm{~B}$ & 1.102239 & 0.540275 & 0.501863 & $0.026^{*}$ \\
$\mathrm{C} 4$ & $0.9292(3)$ & $0.64441(19)$ & $0.56957(10)$ & $0.0174(4)$ \\
$\mathrm{C} 5$ & $0.5877(3)$ & $0.4288(2)$ & $0.59448(12)$ & $0.0231(5)$ \\
$\mathrm{C} 6$ & $0.5765(3)$ & $0.3592(2)$ & $0.71600(12)$ & $0.0313(5)$
\end{tabular}




$\begin{array}{lllll}\text { H6A } & 0.450624 & 0.385732 & 0.724633 & 0.047^{*} \\ \text { H6B } & 0.646158 & 0.367859 & 0.760875 & 0.047^{*} \\ \text { H6C } & 0.579413 & 0.267623 & 0.699820 & 0.047^{*} \\ \text { C7 } & 1.0309(3) & 0.74868(19) & 0.59624(10) & 0.0177(4) \\ \text { C8 } & 1.2227(3) & 0.73732(18) & 0.59618(10) & 0.0189(4) \\ \text { C9 } & 0.9449(3) & 0.86551(18) & 0.62494(10) & 0.0184(4) \\ \text { C10 } & 1.0050(3) & 1.08275(18) & 0.67754(11) & 0.0223(5) \\ \text { C11 } & 1.1811(3) & 1.1505(2) & 0.69862(13) & 0.0316(5) \\ \text { H11A } & 1.259369 & 1.158332 & 0.656003 & 0.047^{*} \\ \text { H11B } & 1.243147 & 1.098650 & 0.735767 & 0.047^{*} \\ \text { H11C } & 1.154341 & 1.238116 & 0.717651 & 0.047^{*} \\ \text { C12 } & 0.9115(3) & 1.1594(2) & 0.61785(12) & 0.0285(5) \\ \text { H12A } & 0.987690 & 1.158864 & 0.574426 & 0.043^{*} \\ \text { H12B } & 0.892301 & 1.250088 & 0.633701 & 0.043^{*} \\ \text { H12C } & 0.794285 & 1.118712 & 0.606871 & 0.043^{*} \\ \text { C13 } & 0.8863(3) & 1.0623(2) & 0.74316(12) & 0.0317(5) \\ \text { H13A } & 0.860354 & 1.147194 & 0.765735 & 0.047^{*} \\ \text { H13B } & 0.949275 & 1.005642 & 0.777859 & 0.047^{*} \\ \text { H13C } & 0.772320 & 1.020617 & 0.728442 & 0.047^{*}\end{array}$

Atomic displacement parameters $\left(\AA^{2}\right)$

\begin{tabular}{lllllll}
\hline & $U^{11}$ & $U^{22}$ & $U^{33}$ & $U^{12}$ & $U^{13}$ & $U^{23}$ \\
\hline O1 & $0.0368(9)$ & $0.0376(9)$ & $0.0386(9)$ & $-0.0201(8)$ & $-0.0091(7)$ & $0.0024(7)$ \\
O2 & $0.0232(7)$ & $0.0229(7)$ & $0.0250(7)$ & $-0.0035(6)$ & $-0.0033(6)$ & $0.0027(6)$ \\
O3 & $0.0129(7)$ & $0.0230(7)$ & $0.0353(8)$ & $0.0011(6)$ & $0.0011(6)$ & $-0.0047(6)$ \\
O4 & $0.0180(7)$ & $0.0152(6)$ & $0.0275(7)$ & $-0.0006(6)$ & $-0.0014(5)$ & $-0.0026(6)$ \\
N1 & $0.0145(8)$ & $0.0154(8)$ & $0.0262(9)$ & $0.0022(7)$ & $-0.0009(6)$ & $-0.0020(7)$ \\
N2 & $0.0182(10)$ & $0.0293(10)$ & $0.0328(10)$ & $-0.0002(7)$ & $-0.0007(7)$ & $-0.0005(8)$ \\
C1 & $0.0182(10)$ & $0.0169(9)$ & $0.0257(10)$ & $-0.0003(8)$ & $-0.0065(8)$ & $-0.0009(7)$ \\
C2 & $0.0265(11)$ & $0.0190(10)$ & $0.0248(10)$ & $-0.0002(9)$ & $-0.0017(8)$ & $-0.0024(8)$ \\
C3 & $0.0196(10)$ & $0.0191(10)$ & $0.0253(10)$ & $0.0038(8)$ & $-0.0003(8)$ & $-0.0015(8)$ \\
C4 & $0.0168(9)$ & $0.0170(10)$ & $0.0184(9)$ & $0.0017(8)$ & $-0.0002(7)$ & $0.0034(8)$ \\
C5 & $0.0182(10)$ & $0.0202(10)$ & $0.0310(12)$ & $0.0001(9)$ & $-0.0045(8)$ & $-0.0021(8)$ \\
C6 & $0.0332(12)$ & $0.0291(11)$ & $0.0315(12)$ & $-0.0038(10)$ & $0.0041(10)$ & $0.0046(9)$ \\
C7 & $0.0140(9)$ & $0.0175(9)$ & $0.0216(10)$ & $0.0015(8)$ & $0.0008(8)$ & $0.0013(8)$ \\
C8 & $0.0193(10)$ & $0.0162(9)$ & $0.0212(10)$ & $-0.0011(8)$ & $0.0013(8)$ & $0.0013(7)$ \\
C9 & $0.0199(10)$ & $0.0163(9)$ & $0.0189(9)$ & $-0.0026(8)$ & $-0.0019(8)$ & $0.0028(8)$ \\
C10 & $0.0254(11)$ & $0.0152(9)$ & $0.0262(11)$ & $0.0005(8)$ & $-0.0007(9)$ & $-0.0029(7)$ \\
C11 & $0.0337(12)$ & $0.0220(10)$ & $0.0391(12)$ & $-0.0057(10)$ & $-0.0048(10)$ & $-0.0058(9)$ \\
C12 & $0.0367(12)$ & $0.0213(10)$ & $0.0276(11)$ & $0.0054(10)$ & $-0.0001(9)$ & $-0.0018(9)$ \\
C13 & $0.0423(13)$ & $0.0272(11)$ & $0.0254(11)$ & $-0.0010(11)$ & $0.0044(10)$ & $-0.0048(9)$ \\
& & & & & & \\
\hline
\end{tabular}

Geometric parameters $\left(\AA,{ }^{\circ}\right)$

\begin{tabular}{llll}
\hline $\mathrm{O} 1-\mathrm{C} 5$ & $1.207(3)$ & $\mathrm{C} 4-\mathrm{C} 7$ & $1.391(3)$ \\
$\mathrm{O} 2-\mathrm{C} 5$ & $1.329(3)$ & $\mathrm{C} 6-\mathrm{H} 6 \mathrm{~A}$ & 0.9800 \\
$\mathrm{O} 2-\mathrm{C} 6$ & $1.456(3)$ & $\mathrm{C} 6-\mathrm{H} 6 \mathrm{~B}$ & 0.9800
\end{tabular}




\begin{tabular}{|c|c|c|c|}
\hline $\mathrm{O} 3-\mathrm{C} 9$ & $1.223(2)$ & $\mathrm{C} 6-\mathrm{H} 6 \mathrm{C}$ & 0.9800 \\
\hline $\mathrm{O} 4-\mathrm{C} 9$ & $1.352(2)$ & $\mathrm{C} 7-\mathrm{C} 8$ & $1.419(3)$ \\
\hline $\mathrm{O} 4-\mathrm{C} 10$ & $1.483(2)$ & $\mathrm{C} 7-\mathrm{C} 9$ & $1.450(3)$ \\
\hline $\mathrm{N} 1-\mathrm{C} 4$ & $1.321(3)$ & $\mathrm{C} 10-\mathrm{C} 13$ & $1.511(3)$ \\
\hline $\mathrm{N} 1-\mathrm{C} 1$ & $1.450(3)$ & $\mathrm{C} 10-\mathrm{C} 12$ & $1.518(3)$ \\
\hline $\mathrm{N} 1-\mathrm{H} 1 \mathrm{~N}$ & $0.81(3)$ & $\mathrm{C} 10-\mathrm{C} 11$ & $1.522(3)$ \\
\hline $\mathrm{N} 2-\mathrm{C} 8$ & $1.159(3)$ & $\mathrm{C} 11-\mathrm{H} 11 \mathrm{~A}$ & 0.9800 \\
\hline $\mathrm{C} 1-\mathrm{C} 5$ & $1.524(3)$ & $\mathrm{C} 11-\mathrm{H} 11 \mathrm{~B}$ & 0.9800 \\
\hline $\mathrm{C} 1-\mathrm{C} 2$ & $1.544(3)$ & $\mathrm{C} 11-\mathrm{H} 11 \mathrm{C}$ & 0.9800 \\
\hline $\mathrm{C} 1-\mathrm{H} 1$ & 1.0000 & $\mathrm{C} 12-\mathrm{H} 12 \mathrm{~A}$ & 0.9800 \\
\hline $\mathrm{C} 2-\mathrm{C} 3$ & $1.537(3)$ & $\mathrm{C} 12-\mathrm{H} 12 \mathrm{~B}$ & 0.9800 \\
\hline $\mathrm{C} 2-\mathrm{H} 2 \mathrm{~A}$ & 0.9900 & $\mathrm{C} 12-\mathrm{H} 12 \mathrm{C}$ & 0.9800 \\
\hline $\mathrm{C} 2-\mathrm{H} 2 \mathrm{~B}$ & 0.9900 & C13-H13A & 0.9800 \\
\hline $\mathrm{C} 3-\mathrm{C} 4$ & $1.506(3)$ & C13-H13B & 0.9800 \\
\hline $\mathrm{C} 3-\mathrm{H} 3 \mathrm{~A}$ & 0.9900 & $\mathrm{C} 13-\mathrm{H} 13 \mathrm{C}$ & 0.9800 \\
\hline $\mathrm{C} 3-\mathrm{H} 3 \mathrm{~B}$ & 0.9900 & & \\
\hline $\mathrm{C} 5-\mathrm{O} 2-\mathrm{C} 6$ & $115.70(16)$ & $\mathrm{H} 6 \mathrm{~A}-\mathrm{C} 6-\mathrm{H} 6 \mathrm{C}$ & 109.5 \\
\hline $\mathrm{C} 9-\mathrm{O} 4-\mathrm{C} 10$ & $120.21(15)$ & $\mathrm{H} 6 \mathrm{~B}-\mathrm{C} 6-\mathrm{H} 6 \mathrm{C}$ & 109.5 \\
\hline $\mathrm{C} 4-\mathrm{N} 1-\mathrm{C} 1$ & $115.28(18)$ & $\mathrm{C} 4-\mathrm{C} 7-\mathrm{C} 8$ & $118.35(18)$ \\
\hline $\mathrm{C} 4-\mathrm{N} 1-\mathrm{H} 1 \mathrm{~N}$ & $119.4(16)$ & $\mathrm{C} 4-\mathrm{C} 7-\mathrm{C} 9$ & $121.41(17)$ \\
\hline $\mathrm{C} 1-\mathrm{N} 1-\mathrm{H} 1 \mathrm{~N}$ & $125.2(16)$ & $\mathrm{C} 8-\mathrm{C} 7-\mathrm{C} 9$ & $120.23(18)$ \\
\hline $\mathrm{N} 1-\mathrm{C} 1-\mathrm{C} 5$ & $113.59(17)$ & $\mathrm{N} 2-\mathrm{C} 8-\mathrm{C} 7$ & $178.6(2)$ \\
\hline $\mathrm{N} 1-\mathrm{C} 1-\mathrm{C} 2$ & $102.49(15)$ & $\mathrm{O} 3-\mathrm{C} 9-\mathrm{O} 4$ & $124.03(17)$ \\
\hline $\mathrm{C} 5-\mathrm{C} 1-\mathrm{C} 2$ & $113.24(15)$ & $\mathrm{O} 3-\mathrm{C} 9-\mathrm{C} 7$ & $123.66(17)$ \\
\hline $\mathrm{N} 1-\mathrm{C} 1-\mathrm{H} 1$ & 109.1 & $\mathrm{O} 4-\mathrm{C} 9-\mathrm{C} 7$ & $112.31(16)$ \\
\hline $\mathrm{C} 5-\mathrm{C} 1-\mathrm{H} 1$ & 109.1 & $\mathrm{O} 4-\mathrm{C} 10-\mathrm{C} 13$ & $109.97(16)$ \\
\hline $\mathrm{C} 2-\mathrm{C} 1-\mathrm{H} 1$ & 109.1 & $\mathrm{O} 4-\mathrm{C} 10-\mathrm{C} 12$ & $109.63(16)$ \\
\hline $\mathrm{C} 3-\mathrm{C} 2-\mathrm{C} 1$ & $104.78(15)$ & $\mathrm{C} 13-\mathrm{C} 10-\mathrm{C} 12$ & $113.13(18)$ \\
\hline $\mathrm{C} 3-\mathrm{C} 2-\mathrm{H} 2 \mathrm{~A}$ & 110.8 & $\mathrm{O} 4-\mathrm{C} 10-\mathrm{C} 11$ & $103.20(16)$ \\
\hline $\mathrm{C} 1-\mathrm{C} 2-\mathrm{H} 2 \mathrm{~A}$ & 110.8 & $\mathrm{C} 13-\mathrm{C} 10-\mathrm{C} 11$ & $110.56(18)$ \\
\hline $\mathrm{C} 3-\mathrm{C} 2-\mathrm{H} 2 \mathrm{~B}$ & 110.8 & $\mathrm{C} 12-\mathrm{C} 10-\mathrm{C} 11$ & $109.90(18)$ \\
\hline $\mathrm{C} 1-\mathrm{C} 2-\mathrm{H} 2 \mathrm{~B}$ & 110.8 & $\mathrm{C} 10-\mathrm{C} 11-\mathrm{H} 11 \mathrm{~A}$ & 109.5 \\
\hline $\mathrm{H} 2 \mathrm{~A}-\mathrm{C} 2-\mathrm{H} 2 \mathrm{~B}$ & 108.9 & $\mathrm{C} 10-\mathrm{C} 11-\mathrm{H} 11 \mathrm{~B}$ & 109.5 \\
\hline $\mathrm{C} 4-\mathrm{C} 3-\mathrm{C} 2$ & $103.35(15)$ & $\mathrm{H} 11 \mathrm{~A}-\mathrm{C} 11-\mathrm{H} 11 \mathrm{~B}$ & 109.5 \\
\hline $\mathrm{C} 4-\mathrm{C} 3-\mathrm{H} 3 \mathrm{~A}$ & 111.1 & $\mathrm{C} 10-\mathrm{C} 11-\mathrm{H} 11 \mathrm{C}$ & 109.5 \\
\hline $\mathrm{C} 2-\mathrm{C} 3-\mathrm{H} 3 \mathrm{~A}$ & 111.1 & $\mathrm{H} 11 \mathrm{~A}-\mathrm{C} 11-\mathrm{H} 11 \mathrm{C}$ & 109.5 \\
\hline $\mathrm{C} 4-\mathrm{C} 3-\mathrm{H} 3 \mathrm{~B}$ & 111.1 & $\mathrm{H} 11 \mathrm{~B}-\mathrm{C} 11-\mathrm{H} 11 \mathrm{C}$ & 109.5 \\
\hline $\mathrm{C} 2-\mathrm{C} 3-\mathrm{H} 3 \mathrm{~B}$ & 111.1 & $\mathrm{C} 10-\mathrm{C} 12-\mathrm{H} 12 \mathrm{~A}$ & 109.5 \\
\hline $\mathrm{H} 3 \mathrm{~A}-\mathrm{C} 3-\mathrm{H} 3 \mathrm{~B}$ & 109.1 & $\mathrm{C} 10-\mathrm{C} 12-\mathrm{H} 12 \mathrm{~B}$ & 109.5 \\
\hline $\mathrm{N} 1-\mathrm{C} 4-\mathrm{C} 7$ & $125.43(18)$ & $\mathrm{H} 12 \mathrm{~A}-\mathrm{C} 12-\mathrm{H} 12 \mathrm{~B}$ & 109.5 \\
\hline $\mathrm{N} 1-\mathrm{C} 4-\mathrm{C} 3$ & $109.30(17)$ & $\mathrm{C} 10-\mathrm{C} 12-\mathrm{H} 12 \mathrm{C}$ & 109.5 \\
\hline $\mathrm{C} 7-\mathrm{C} 4-\mathrm{C} 3$ & $125.26(17)$ & $\mathrm{H} 12 \mathrm{~A}-\mathrm{C} 12-\mathrm{H} 12 \mathrm{C}$ & 109.5 \\
\hline $\mathrm{O} 1-\mathrm{C} 5-\mathrm{O} 2$ & $124.1(2)$ & $\mathrm{H} 12 \mathrm{~B}-\mathrm{C} 12-\mathrm{H} 12 \mathrm{C}$ & 109.5 \\
\hline $\mathrm{O} 1-\mathrm{C} 5-\mathrm{C} 1$ & $122.31(19)$ & $\mathrm{C} 10-\mathrm{C} 13-\mathrm{H} 13 \mathrm{~A}$ & 109.5 \\
\hline $\mathrm{O} 2-\mathrm{C} 5-\mathrm{C} 1$ & $113.59(16)$ & $\mathrm{C} 10-\mathrm{C} 13-\mathrm{H} 13 \mathrm{~B}$ & 109.5 \\
\hline $\mathrm{O} 2-\mathrm{C} 6-\mathrm{H} 6 \mathrm{~A}$ & 109.5 & $\mathrm{H} 13 \mathrm{~A}-\mathrm{C} 13-\mathrm{H} 13 \mathrm{~B}$ & 109.5 \\
\hline $\mathrm{O} 2-\mathrm{C} 6-\mathrm{H} 6 \mathrm{~B}$ & 109.5 & $\mathrm{C} 10-\mathrm{C} 13-\mathrm{H} 13 \mathrm{C}$ & 109.5 \\
\hline
\end{tabular}




$\begin{array}{llll}\mathrm{H} 6 \mathrm{~A}-\mathrm{C} 6-\mathrm{H} 6 \mathrm{~B} & 109.5 & \mathrm{H} 13 \mathrm{~A}-\mathrm{C} 13-\mathrm{H} 13 \mathrm{C} & 109.5 \\ \mathrm{O} 2-\mathrm{C} 6-\mathrm{H} 6 \mathrm{C} & 109.5 & \mathrm{H} 13 \mathrm{~B}-\mathrm{C} 13-\mathrm{H} 13 \mathrm{C} & 109.5 \\ \mathrm{C} 4-\mathrm{N} 1-\mathrm{C} 1-\mathrm{C} 5 & 109.61(19) & \mathrm{N} 1-\mathrm{C} 1-\mathrm{C} 5-\mathrm{O} 2 & -26.3(2) \\ \mathrm{C} 4-\mathrm{N} 1-\mathrm{C} 1-\mathrm{C} 2 & -12.9(2) & \mathrm{C} 2-\mathrm{C} 1-\mathrm{C} 5-\mathrm{O} 2 & 90.1(2) \\ \mathrm{N} 1-\mathrm{C} 1-\mathrm{C} 2-\mathrm{C} 3 & 20.43(19) & \mathrm{C} 3-\mathrm{C} 4-\mathrm{C} 7-\mathrm{C} 8 & -2.4(3) \\ \mathrm{C} 1-\mathrm{N} 1-\mathrm{C} 4-\mathrm{C} 7 & -179.84(18) & \mathrm{N} 1-\mathrm{C} 4-\mathrm{C} 7-\mathrm{C} 9 & -2.1(3) \\ \mathrm{C} 1-\mathrm{N} 1-\mathrm{C} 4-\mathrm{C} 3 & -0.6(2) & \mathrm{C} 10-\mathrm{O} 4-\mathrm{C} 9-\mathrm{O} 3 & -2.1(3) \\ \mathrm{C} 2-\mathrm{C} 3-\mathrm{C} 4-\mathrm{N} 1 & 14.0(2) & \mathrm{C} 4-\mathrm{C} 7-\mathrm{C} 9-\mathrm{O} 3 & -1.4(3) \\ \mathrm{C} 6-\mathrm{O} 2-\mathrm{C} 5-\mathrm{O} 1 & -2.2(3) & \mathrm{C} 8-\mathrm{C} 7-\mathrm{C} 9-\mathrm{O} 4 & 0.4(3) \\ \mathrm{C} 6-\mathrm{O} 2-\mathrm{C} 5-\mathrm{C} 1 & 179.93(16) & \mathrm{C} 9-\mathrm{O} 4-\mathrm{C} 10-\mathrm{C} 13 & 61.8(2) \\ \mathrm{N} 1-\mathrm{C} 1-\mathrm{C} 5-\mathrm{O} 1 & 155.73(19) & & \end{array}$

Hydrogen-bond geometry $\left(\AA,{ }^{\circ}\right)$

\begin{tabular}{lllll}
\hline$D-\mathrm{H} \cdots A$ & $D-\mathrm{H}$ & $\mathrm{H} \cdots A$ & $D \cdots A$ & $D-\mathrm{H} \cdots A$ \\
\hline $\mathrm{N} 1-\mathrm{H} 1 N \cdots \mathrm{O} 3$ & $0.81(3)$ & $2.13(2)$ & $2.714(2)$ & $129(2)$ \\
$\mathrm{N} 1-\mathrm{H} 1 N \cdots \mathrm{N} 2^{\mathrm{i}}$ & $0.81(3)$ & $2.33(2)$ & $2.924(2)$ & $131(2)$ \\
$\mathrm{C} 11-\mathrm{H} 11 B \cdots \mathrm{O} 2^{\mathrm{ii}}$ & 0.98 & 2.60 & $3.565(3)$ & 169 \\
\hline
\end{tabular}

Symmetry codes: (i) $x-1, y, z$; (ii) $-x+2, y+1 / 2,-z+3 / 2$. 